\title{
PERAN GURU BIMBINGAN DAN KONSELING DAN GURU AKIDAH AKHLAK DALAM MEMBIMBING AKHLAK SISWA KELAS VIII SMP MUHAMMADIYAH 1 YOGYAKARTA TAHUN AJARAN 2019/2020
}

\author{
Nisa Alfionita ${ }^{1}$, Makin $^{2}$ \\ Program Sarjana Bimbingan dan Konseling \\ Fakultas Keguruan dan Ilmu Pendidikan \\ Universitas PGRI Yogyakarta \\ E-mail: makinsh11@gmail.com
}

\begin{abstract}
Abstrak
Penelitian bertujuan mendeskripsikan: upaya bimbingan yang dilakukan oleh guru bimbingan dan konseling dan guru akidah akhlak, capaian hasil bimbingan, faktor pendukung dan penghambat pelaksanaan bimbingan. Penelitian menerapkan pendekatan fenomenologi dengan metode deskriptif kualitatif. Pengumpulan data menggunakan wawancara mendalam dan observasi dengan sumber data: guru bimbingan dan konseling, guru mata pelajaran akidahakhlak, dan 3 perwakilan siswa kelas VIII SMP Muhammadiyah 1 Yogyakarta. Analisis data menerapkan tahapan proses reduksi data, penyajian data, dan penarikan kesimpulan. Hasil penelitian ini upaya preventif dari guru bimbingan dan konseling melalui pemberian layanan bimbingan dan konseling bidang pribadi-sosial, sedangkan guru akidah-ahlak melaksanakannya melalui tugas pembelajaran akidah-ahlak di kelas. Upaya yang bersifat kuratif berupa penanganan kasus pelanggaran atau perilaku menyimpang dari norma etika/ahlak, menggunakan metode penasehatan, teguran, hukuman, kolaborasi teman sejawat dan orangtua siswa. Hasil bimbingan menunjukkan peningkatan pemahaman dan sikap positif siswa terhadap pengamalan ahlak yang baik. Faktor pendukung bimbingan berupa peranserta semua pihak di sekolah dan orangtua siswa, faktor budaya, dan pemberian penghargaa dari sekolah. Sedangkan faktor yang menghambat bersumber dari kurangnya pemahaman agama dan perhatian dari sebagaian orangtua siswa.
\end{abstract}

Kata kunci : peran guru bk, guru akidah-ahlak, ahklak siswa

\begin{abstract}
The research aims to describe: the guidance efforts undertaken by the guidance and counseling teacher and moral teacher, the achievement of the results of the guidance, supporting factors and obstacles to the implementation of the guidance. The study applied a phenomenological approach with qualitative descriptive methods. Data collection using in-depth interviews and observations with data sources: guidance and counseling teachers, moral subjects, and 3 representatives of class VIII students of SMP Muhammadiyah 1 Yogyakarta. Data analysis applies the stages of the process of data reduction, data presentation, and drawing conclusions. The results of this study preventive efforts from the guidance and counseling teacher through the provision of guidance and counseling services in the private-social field, while the creed teachers implement it through the task of learning creed-ahlak in class. Curative efforts in the form of handling cases of violations or deviant behavior from ethical norms / practice, using the method of counseling, reprimand, punishment, collaboration of colleagues and parents of students. The results of the guidance show an increase in students' understanding and positive attitude towards good practice. Guidance supporting factors include participation of all parties in the school and parents, cultural factors, and the awarding of the school. While the inhibiting factors stem from a lack of religious understanding and attention from some parents of students. Keywords: the role of the teacher bk, the teacher of faith-ahlak, ahklak students
\end{abstract}

\section{Info Artikel}

Diterima Februari 2020, disetujui Maret 2020, diterbitkan Juni 2020 


\section{PENDAHULUAN}

Siswa pada Sekolah Menengah Pertama berada pada posisi perkembangan masa remaja awal dengan dinamika perubahan yang pesat dan cepat dalam berbagai aspek, termasuk aspek moral atau ahlak. Perubahan yang cepat seringkali menimbulkan krisis, oleh karena itu dinamika perubahan perkembangan pada masa remaja mendapat perhatian serius dari berbagai pihak khususnya para pendidik karena pengalaman menjalani perkembangan masa remaja menentukan perkembangan individu remaja pada tahap selanjutnya yaitu masa dewasa.

Di Sekolah Menengah Pertama, guru adalah seorang pendidik yang sehari-hari berinteraksi secara intens dengan sosok remaja yang menjadi siswa dengan segala problematikanya. Sesuai dengan tugas utama guru yaitu mendidik dan membelajarkan siswa maka guru diharapkan dapat berperan optimal dalam pengatasan masalah siswa sebagai bagian dari upaya memfasilitasi perkembangan berbagai aspek yang menunjang pencapaian tujuan pendidikan.

Menurut Voaindonesia.com (11-02-2019), persoalan yang dihadapi oleh guru saat ini adalah masalah krisis akhlak di kalangan siswa. Seperti siswa yang bersekolah di salah satu SMP daerah Gresik yang menantang dengan memegang kerah seorang guru sambil memposisikan tangan seperti hendak memukul si guru, dikarenakan siswa tersebut tidak terima lantaran ditegur saat merokok di dalam kelas. Hasil penelitian Muchtar (2005) juga menyatakan beberapa siswa sekolah menengah memiliki ahlak yang tidak sesuai dengan nilai dan norma yang berlaku, seperti berbicara kurang sopan, kurang menghargai guru, merokok, dan berkelahi.

Kenakalan remaja yang terjadi di beberapa tempat seringkali dikaitkan dengan tanggung jawab guru di sekolah. Walaupun pelaku kenakalan belum tentu siswa namun karena kebanyakan pelaku adalah remaja dalam usia sekolah maka guru menjadi sasaran. Hal ini sesungguhnya mencerminkan adanya harapan yang sangat kuat dari masyarakat kepada guru, bukan hanya mengajar tetapi juga mendidik. Dalam konteks tugas mendidik guru dikenal sebagai pribadi yang harus bisa "digugu dan ditiru" yang intinya adalah keteladanan menjadi hal yang sangat penting dari performance guru, baik di sekolah maupun di luar sekolah.

Menurut Mulyasa (2012: 63) guru adalah orang yang berwenang dan bertanggung jawab terhadap pendidikan siswanya, membimbing dan membina siswanya 
baik secara individu maupun kelompok. Dalam kaitan ini semua guru memiliki peran yang sama dalam memberikan pendidikan karakter kepada siswa. Muchlas Samani dan Haryanto (2011: 2) menyebutkan pendidikan karakter di Indonesia dirasakan amat perlu pengembangannya bila mengingat makin meningkatnya tawuran antar pelajar, serta bentuk-bentuk kenakalan remaja lainnya terutama di kota-kota besar, pemerasan/kekerasan (bullying), kecenderungan dominasi senior terhadap junior, penggunaan narkoba, dan lain-lain.

Pendidikan karakter di sekolah sangat diperlukan walaupun dasar dari pendidikan karakter adalah di dalam keluarga. Apabila seorang anak mendapatkan pendidikan karakter yang baik dari keluarganya maka anak tersebut akan berkarakter baik pada tahap selanjutnya. Namun banyak orang tua yang lebih mementingkan aspek kecerdasan otak ketimbang pendidikan karakter. Menurut Daniel Golenam (dalam Masnim Muslich, 2011: 30) banyak orang tua yang gagal dalam mendidik karakter anak-anaknya baik karena kesibukan maupun karena lebih mementingkan aspek kognitif anak. Meskipun demikian kondisi ini dapat ditanggulangi dengan memberikan pendidikan karakter di sekolah.

Membimbing ahlak siswa merupakan bagian dari pendidikan karakter di sekolah. Dalam kaitan ini guru bimbingan dan konseling memiliki posisi strategis dalam mewujudkan perannya secara optimal. Sebagaimana dijelaskan dalam Permendikbud Nomor 111 tahun 2014 Pasal 1 Ayat 1, Bimbingan dan Konseling adalah upaya sistematis, objektif, logis, dan berkelanjutan serta terprogram yang dilakukan oleh konselor atau guru Bimbingan dan Konseling untuk memfasilitasi perkembangan siswa/konseli untuk mencapai kemandirian dalam kehidupannya. Sebagai bagian terpadu program pendidikan, pelayanan bimbingan dan konseling diarahkan kepada upaya untuk memfasilitasi siswa mengenal dan menerima dirinya sendiri serta lingkungannya secara positif dan dinamis, dan mampu mengambil keputusan, mengembangkan serta mewujudkan diri secara efektif dan produktif, sesuai dengan peranaan yang diinginkan masa depan serta menyangkut upaya memfasilitasi siswa agar mampu mengembangkan potensi dirinya mencapai tugas-tugas perkembangan secara optimal.

Peran guru bimbingan dan konseling dalam memfasilitasi perkembangan siswa ke arah tercapainya kemandirian diwujudkan melalui pemberian layanan dalam bidang 
pribadi, sosial, belajar, dan karir. Membimbing ahlak siswa yang substansinya berhubungan dengan perkembangan aspek afeksi dan moral, menjadi bagian penting dari keseluruhan layanan bimbingan dan konseling di sekolah yang secara spesifik diwujudkan dalam kegiatan aktual layanan bimbingan bidang pribadi-sosial

Pada lembaga pendidikan Muhammadiyah, pembinaan atau bimbingan ahlak siswa berada pada ruang lingkup pendidikan/pembelajaran ISMUBA (Ke-Islaman, KeMuhammadiyahan, dan Bahasa Arab) yang terdiri dari Pendidikan Al-Qur'an Hadist (Tahsin Tilawah, Tahfidz), Pendidikan Akidah-Akhlak, Pendidikan Fikih, Pendidikan Tarikh Islam, Pendidikan Kemuhammadiyahan, Pendidikan Bahasa Arab. Pendidikan Ismuba memiliki tujuan untuk menumbuh kembangkan akidah melalui pengalaman dan pembiasaan tentang Al-Islam, mewujudkan manusia yang taat beragama dan berakhlakul karimah yakni manusia yang berpengetahuan, rajin beribadah, cerdas, jujur, serta disiplin. Menurut Suliswiyadi (2013: 72) Ismuba adalah pelajaran yang sangat penting karena menjadi ciri khas yang membedakan sekolah lain dengan sekolah Muhammadiyah. Salah satu materi pembelaran yang menjadi perhatian utama adalah materi tentang akidah akhlak, karena terwujudnya akhlak mulia ditengah-tengah masyarakat merupakan misi utama pembelajaran Ismuba.

Dengan demikian pembinaan ahlak siswa di SMP Muhammadiyah 1 Yogyakarta selain menjadi fokus kinerja guru akidah-ahlak juga diperkuat melalui pelaksanaan bimbingan bidang pribadi-sosial. Artinya koordinasi dan sinergitas peran guru akidahahlak dengan guru bimbingan dan konseling dalam membimbing ahlak siswa sangat dimungkinkan dan tentunya hal itu berdampak pada capaian hasil yang lebih optimal. Namun dari hasil pengamatan selama menjalankan tugas Praktik Pengalaman Lapangan ditemukan banyak siswa yang perilakunya belum mencerminkan ahlak yang baik, baik dalam hal kepatuhan terhadap peraturan sekolah, berbicara dengan teman di lingkungan sekolah, terjadinya bullying antar siswa, datang terlambat padahal jam pelajaran sudah dimulai, dan terlambat mengumpulkan tugas-tugas yang diberikan oleh guru. Hal ini mengindikasikan bahwa layanan bimbingan dan konseling serta layanan pembelajaran akidah-ahlak belum yang diharapkan dapat memberikan bimbingan/ pembinaan ahlak kepada siswa belum menunjukkan hasil yang optimal. 


\section{METODE PENELITIAN}

Penelitian dilakukan di SMP Muhammadiyah 1 Yogyakarta dengan menggunakan pendekatan fenomenologi. Pendekatan fenomenologi bertujuan untuk mendeskripsikan paradigm atau cara pandang terhadap realitas. Oleh karena itu, penelitian fenomenologi berorientasi untuk memahami, menggali, menafsirkan, dan memberikan makna dari peristiwa-peristiwa, fenomena, dan hubungannya dengan manusia dalam situasi tertentu (Musfiqun, 2012: 71). Dengan fokus penelitian tentang peran guru bimbingan dan konseling, dan guru akidah-akhlak dalam pembinaan/membimbing akhlak siswa kelas VIII di SMP Muhammadiyah 1 Yogyakarta maka peneliti bertujuan mendeskripsikan realitas upaya yang dilakukan oleh guru bimbingan dan konseling, dan guru akidah-akhlak dalam membimbing akhlak siswa, hasil yang dicapai, serta faktor pendukung dan penghambat dalam pelaksanaannya.

Pengumpulan data menggunakan metode trianggulasi melalui wawancara mendalam dan observasi. Sumber data penelitian meliputi guru bimbingan dan konseling, guru mata pelajaran akidah akhlak, dan 3 perwakilan siswa kelas VIII SMP Muhammadiyah 1 Yogyakarta. Analisis data dilakukan dengan menerapkan model analisis Miles And Huberman (Salim dan Syahrum, 2007: 147) sebagai aktivitas yang dilakukan secara interaktif dan berlangsung secara terus-menerus sampai tuntas, sehingga datanya sudah jenuh. Aktivitas analisis data yang dimaksud meliputi: 1) Data Reduction (Reduksi Data) yaitu merangkum dan mengkategorikan data hasil penelitian, memilih hal-hal yang pokok, memfokuskan pada hal-hal yang penting, dicari tema dan polanya; 2) Data Display (Penyajian Data), yaitu menyajikan data dalam bentuk uraian singkat atau bagan hubungan antar kategori data; dan 3) Conclusion (Penarikan Kesimpulan). Pengecekan keabsahan data dilakukan dengan menerapkan teknik trianggulasi sumber dan metode (John W. Creswell, 2014: 229). Triangulasi sumber dilakukan dengan cara mengecek data yang diperoleh dari guru dengan data yang diperoleh dari siswa, sedangkan triangulasi metode dilakukan dengan cara mengecek data hasil wawancara dengan data hasil observasi, dan memastikan data yang diperoleh tidak saling bertentangan. 


\section{HASIL DAN PEMBAHASAN}

\section{Upaya Pembinaan Ahlak Siswa Oleh Guru Bimbingan dan Konseling dan Guru}

\section{Akidah Akhlak}

Sesuai tugas pokok dalam penyelenggaraan bimbingan dan konseling, guru bimbingan dan konseling di SMP Muhammadiyah 1 Yogyakarta menjalankan peran secara preventif dan kuratif. Peran secara preventif diwujudkan melalui layanan informasi dengan tema-tema tertentu, antara lain ketaatan pada aturan, pentingnya kejujuran, etika dalam pergaulan, yang diharapkan menjadi pengalaman belajar sebagai dasar dalam berperilaku yang baik dalam kehidupan sehari-hari. Selain itu, guru bimbingan dan konseling juga memberikan keteladan dalam perkataan maupun perbuatan, termasuk dalam menjalankan kegiatan keislaman yang menjadi ketentuan sekolah, antara lain sholat berjamaah dan tadarus Al-qur'an. Dalam konteks pendidikan karakter yang menjadi tanggung jawab semua guru maka guru bimbingan dan konseling turut serta berperan dalam proses pembiasaan berperilaku baik kepada siswa. Sedangkan peran secara kuratif diwujudkan dalam proses penanganan kasus kenakalan siswa dan penasehatan berkaitan dengan pelanggaran terhadap tata tertib atau peraturan sekolah, serta perilaku menyimpang seperti bullying, aksi cerat-coret dinding, dan perilaku tidak sopan di sekolah

Bagi guru akidah-akhlak peran pembinaan ahlak peserta didik menjadi fokus utama dalam menjalankan tugas menanamkan dasar keilmuan untuk pembentukan akhlak kepada siswa. Peran tersebut dijalankan secara terus menerus baik melalui proses pembelajaran dan tugas-tugas yang menunjang capaian hasil pembelajaran. Dalam proses pembelajaran di kelas guru melakukan pembiasaan mengawali kegiatan dengan memberikan salam kepada siswa kemudian memeriksa keadaan kelas dan tata tertib siswa seperti kebersihan, ketertiban, keindahan, kesehatan, kekeluargaan, keamanan, dan keagamaan yang diterapkan guru dengan membaca doa dan surat pendek dalam Alqur,an secara bersama-sama. Demikian pula pada saat mengahiri kegiatan pembelajaran guru mengajak siswa untuk berdoa bersama. Di luar pembelajaran, pembinaan ahlak dilakukan melalui pemberian contoh keteladanan dan pola pembiasaan perilaku mentaati aturan agama Islam, baik dalam pelaksanaan ibadah maupun dalam berinteraksi dengan guru dan sesame siswa. Pemantauan pengamalan nilai-kalai dasar pembentukan karakter yang menjadi misi sekolah juga menjadi bagian peran guru 
akidah-ahlak di luar jam pelajaran. Selain itu guru akidah-ahlak juga melakukan penanganan perilaku menyimpang yang dilakukan oleh siswa dengan cara memberikan nasehat atau peringatan secara lisan. Apabila dengan peringatan tersebut siswa belum mampu memperbaiki, guru menindak lanjuti dengan memberikan hukuman menulis dan menghafal bagian dari surat-surat tertentu dalam Al-Qur'an dengan maksud memberikan efek jera kepada siswa. Dalam kasus tertentu penanganan dilakukan melalui kerjasama dengan guru bimbingan dan konseling serta pertemuan dengan orangtua siswa.

\section{Capaian Hasil Pembinaan Ahlak Siswa}

Hasil pembinaan ahlak yang secara nyata dapat diamati antara lain semakin meningkat kedisiplinan siswa, baik ketika datang pagi memasuki gerbang sekolah setiap hari siswa mengucapkan salam dan bersalaman dengan kepala sekolah, guru piket dan petugas satpam, kedisiplinan dalam berpakaian dan penampilan diri yang baik, serta dalam melakukan kebersihan kelas dan penggunaan sarana/prasarana sekolah.

Berkaitan dengan penanganan kasus yang tidak mencerminkan ahlak yang baik, capaian hasilnya menjukkan semakin berkurang, terutama menyangkut pelanggaran tata tertib dan norma moral oleh siswa yang berasal dari sekolah yang bukan berlatar belakang keagamaan termasuk muhammadiyah. Walaupun belum bisa dikatakan berhasil sepenuhnya, namun dalam tataran pemahaman dan sikap positif terhadap perwujudan ahlak yang baik menjunjukkan adanya peningkatan yang signifikan. Sedangkan pada tataran perilaku nyata, keberhasilannya masih dalam batas jika siswa telah mendapatkan hukuman dari guru atas pelanggaran aturan sekolah atau tidak sesuai dengan norma etika/ahlak yang baik. Kondisi demikian dapat dipahami terkait dinamika kehidupan remaja yang sangat komplek ditengah derasnya pengaruh negatif dari lingkungan, sebagaimana dinyakan oleh siswa yang menjadi subyek penelitian.

\section{Faktor Pendukung Pembinaan Akhlak Siswa}

a. Peran serta para guru dan karyawan terkait dengan tugas dalam pelaksanaan pendidikan karakter kepada siswa. Dalam kaitan ini faktor budaya khususnya pola perilaku masyarakat yogya yang mengedepankan kehalusan dan keluhuran budi pekerti sangat menunjang keterlibatan semua pihak di lingkungan sekolah 
berperanserta dalam pembinaan ahlak siswa. Artinya, keteladanan maupun kontrol terhadap pengamalan etika/ahlak dapat ditemukan siswa diluar yang dilakukan oleh guru bimbingan dan konseling maupun guru akidah-ahlak

b. Pengaruh Orangtua Siswa. Salah satu pertimbangan utama orangtua memasukkan anaknya di SMP Muhammadiyah 1 Yogyakarta adalah agar anak mendapat pendidikan plus, artinya selain mendapatkan pengetahuan juga pembinaan ahlak yang baik. Oleh karena itu orangtua siswa secara umum mendukung dan bersedia dilibatkan dalam kegiatan pembinaan ahlak siswa, misalnya mendukung kebijakan melarang anak membawa HP ke sekolah dan memakai ciput untuk siswa putri.

c. Penghargaan (Reward). Penghargaan atau reward yang dimaksud disini adalah pujian, sanjungan, atau pemberian sesuatu dari guru kepada siswa yang berahlak baik (siswa teladan) dan khususnya kepada siswa yang menunjukkan perubahan positif setelah mendapatkan penangan atas perilakunya yang tidak baik atau melakukan pelanggararan.

\section{Faktor Penghambat Pembinaan Akhlak Siswa}

a. Kurangnya pendidikan agama dan perhatian dari sebagian orang tua siswa. Kesibukan orang tua melaksanakan kegiatannya terkadang sampai melupakan tugas dan tanggung jawab mendidik anaknya. Karena pada umumnya ketika orang tua menyekolahkan anaknya mereka merasa tugas dan tanggung jawab pendidikan sepenuhnya telah diserahkan pada pihak sekolah. Dalam konteks pembinaan ahlak, orang tua adalah figur utama teladan bagi anak. Apa yang diperbuat orang tua akan ditiru oleh anak. Oleh karena itu kebiasaan atau perilaku orang tua siswa yang tidak mencerminkan ahlak yang baik menjadi kendala keberhasilan pembinaan ahlak bagi siswa. Misalnya cara orangtua dalam bergaul dengan tetangga atau bahkan cara memperlakukan anak di rumah, kebiasaan sholat berjama'ah, dan membaca alQur'an, menjadi rujukan perilaku anak

b. Kurang kesadaran dari diri siswa untuk melakukan kegiatan keagamaan. Pada umumnya siswa ketika diluar jam sekolah lebih senang menghambur-hamburkan waktunya untuk sendau gurau, bermain, jalan-jalan kesana kemari untuk mencari kesenangan. Bukan tidak mungkin hal semacam itu bisa melalikan norma etika/ahlak. 
c. Pengaruh Teman. Teman merupakan orang yang sangat berpengaruh bagi tingkah laku seorang anak. Teman yang baik akan memberi pengaruh yang baik bagi seorang siswa, begitu pula sebaliknya. Hal ini terjadi karena teman yang selalu bersama sehari-hari di sekolah, mungkin juga di luar sekolah menjadi sumber identifikasi dirinya. Contoh kasus yang sering terjadi di sekolah misalnya saat jam istirahat, ada salah satu siswa mengejek siswa yang lain maka spontan teman dari siswa yang diejek ikut-ikutan membalas apa yang dilakukan temannya. Hal ini berlanjut menjadi saling membully antar kelompok.

\section{KESIMPULAN}

Berdasarkan temuan hasil penelitian dapat disimpulkan bahwa guru bimbingan dan konseling, dan guru akidah-ahlak berperan penting dalam pembinaan/ membimbing ahlak siswa. Peran kedua pihak diwujudkan melalui berbagai upaya yang bersifat preventif dan kuratif. Upaya preventif dari guru bimbingan dan konseling dilaksanakan melalui pemberian layanan informasi bidang pribadi-soasial, sedangkan guru akidahahlak melaksanakannya melalui tugas pembelajaran akidah-ahlak di kelas. Guna menunjang keberhasilan upaya preventif diluar pelaksanaan tugas pokok yang berbeda tersebut, kedua pihak menerapkan metode keteladanan dan pembiasaan berperilaku baik/berahlak baik. Dalam upaya yang bersifat kuratif berupa penanganan kasus pelanggaran atau perilaku menyimpang dari norma etika/ahlak, guru akidah-ahlak menggunakan metode penasehatan, teguran, dan hukuman yang mempunyai efek jera tetapi tidak melanggar azas mendidik yaitu menulis atau menghafal ayat/surat pendek dalam Al-qur,an. Dalam hal ini peran guru bimbingan dan konseling bekerjasama dengan guru akidah-ahlak. Dalam penangan kasus tertentu guru bimbingan dan konseling juga melakukan peran bersama orangtua siswa untuk menemukan solusinya.

Hasil yang dicapai dari upaya pembinaan ahlak yang dilakukan oleh guru bimbingan dan konseling, dan guru akidah-ahlak menunjukkan bahwa semua siswa mempunyai pemahaman yang cukup serta sikap positif/apresiatif terhadap pengamalan ahlak/perilaku baik. Namun pada tataran pelaksanaan dalam kehidupan sehari-hari belum menunjukkan hasil yang optimal, karena masih ada beberapa siswa yang berperilaku tidak sesuai dengan yang diharapkan

Capaian hasil pembinaan ahlak siswa tidak terlepas dari adanya faktor 
pendukung dan penghambat. Faktor pendukung pelaksanaan pembinaan ahlak siswa antara lain adanya peranserta semua pihak di lingkungan sekolah terkait dengan tanggung jawab bersama pendidikan/pembinaan karakter siswa, faktor budaya yogya yang mengedepankan keluhuran budi pekerti, peranserta orangtua siswa, dan adanya penghargaan dari sekolah kepada siswa yang berprestasi. Sedangkan faktor penghambatnya antara lain bersumber dari kurangnya pemahaman agama dan perhatian dari sebagaian orangtua siswa, kesadaran siswa yang masih fluktuatif dalam etika/berahlak baik, serta pengaruh negatif dari teman atau kelompok.

\section{DAFTAR PUSTAKA}

Anwar, R. 2010. Akhlak Tasawuf. Bandung: CV Pustaka Setia

Creswell, J. W. 2014. Research Design. Yogyakarta: Pustaka Pelajar

Effendi, K. 2016. Proses dan Keterampilan Konseling. Yogyakarta: Pustaka Pelajar

Jamaluddin, D. 2013. Paradigma Anak dalam Islam. Bandung: CVPustaka Setia

Johansyah. Pendidikan Karakter Dalam Islam Dari Aspek Metodologi Dalam Islam Futura. Vol. XI, No. 1 Agustus 2011

Lumongga, L. 2011. Mamahami Dasar-Dasar Konseling Dalam Teori dan Praktik. Jakarta: Prenada media Group

Muchtar. 2005. Perilaku Akhlaqul Karimah Siswa: Survei Di Smu Unj. Kontekstualita. 20(2): 73

Mulyasa. 2012. Manajemen Pendidikan Karakter. Jakarta: BUMI AKSARA

Musfiqun. 2012. Metodologi Penelitian Pendidikan. Jakarta: PT Prestasi Pustakaraya

Muslich, M. 2011. Pendidikan Karakter: Menjawab Tantangan Krisis Multidimensional. Jakarta: PT Bumi Aksara

Mustaqib, A. 2013. Akhlak Tasawuf; Lelaku Suci Menuju Revolusi Hati. Yogyakarta: Kaukaba Dibantara

Nasharuddin. 2015. Akhlak; Ciri Manusia Paripurna. Depok: PT Raja Grapindi Persada

Permendikbud No. 111 Tahun 2014 Pasal 1 Ayat 1

Salim., dan Syahrum. 2016. Metodologi Penelitian Kualitatif. Bandung: Cipta Pustaka Media

Samani, M., dan Hariyanto. 2011. Konsep dan Model Pendidikan Karakter. Bandung: PT Remaja Rosdakarya 
Sukmadinata, N. S. 2007. Bimbingan dan Konseling dalam Praktek Mengembangkan Potensi dan Kepribadian Siswa. Bandung: Maestro

Suliswiyadi. 2013. Al-Islam Reflektif. Magelang: Ummal Press

Syamhudi, H. 2015. Akhlak Tasawuf. Malang: Madani Media

Tim Pengembang Kurikulum Dikdasmen PWM. 2012. Kurikulum ISMUBA. Yogyakarta: Majelis Dikdasmen PWM

Undang-Undang No. 20 Tahun 2003 Pasal 13 Ayat 1 tentang Sistem Pendidikan Nasional

Yusuf, S. L. N. 2017. Bimbingan dan Konseling Perkembangan Suatu Pendekatan Komprehensif. Bandung: PT Refika Aditama

Zubaedi. 2013. Desain Pendidikan Karakter; Kompetensi dan Aplikasinya dalam Lembaga Pendidikan. Jakarta: Prenada Media Group 